\title{
Democratic education in the Deweyan perspective and the challenges of African development
}

\author{
Isaiah Aduojo Negedu \\ Department of General Studies, Faculty of Arts, Federal University Lafia, Nasarawa State, Nigeria
}

Email address:

aduojo2000@yahoo.com

To cite this article:

Isaiah Aduojo Negedu. Democratic Education in the Deweyan Perspective and the Challenges of African Development. International Journal of Philosophy. Vol. 2, No. 2, 2014, pp. 21-25. doi: 10.11648/j.ijp.20140202.11

\begin{abstract}
The global community has come to live with the idea of formal education as a tool for political governance. With the upsurge of colonialism, the evolution of education varies from one country to another. Generally, Africans have taken little positive steps to promoting education for democratic governance as we experience slow pace of educational development due to the absence of proper enlightenment. Our aim is to analyze the concept of education and x-ray its connection to the political development of Africa. In the final analysis, we aver that while the political development of a people cannot be divorced from the nature of their educational system, our post colonial history shows that we barely remain at the level of mere speculation until our theories are responsibly put into effective use that produce results.
\end{abstract}

Keywords: Experience, Democracy, Education

\section{Introduction}

With the advent of enlightenment and the rebirth of philosophy, humanism came to limelight. The educational thought of Dewey revolves around the concept of pragmatic instrumentalism, which focuses on the human-centeredness of all disciplines. It is a progression of his idea that insists that knowledge should be a tool for action. Thus, the emphasis is on the place of the human person in the universe. What is learnt in the school environment therefore must be translated into action in the wider society. He carries his notion of instrumentalism to all ramifications of human endeavour. Human beings are free and as such, they ought to be rational and responsible for their affairs and decisions they take in life. The question of having a knowledge that is translated into action in the wider society would keep anyone puzzled who has ventured into Dewey's outlook.

\section{Problems of Men}

The problem of men is Dewey's attempt to situate the origin of man's plight. It was his belief that other epistemologies, whether rationalist or empiricist had drawn too bare a distinction between thought and the world of fact. Thought was believed to exist apart from the world epistemically as the object of immediate awareness, and ontologically as the unique aspect of the self. He was bothered by the fact of the idea that nature was inherently rational. In this case, reason paraded itself as being complete within itself. Dewey believed that humans were not souls existing apart from the natural world but creatures residing in nature.

The world of fact does not stand apart from thought, but is itself defined within thought as its objective manifestation. That was why he defined his entire goal as an attempt to obtain a moderately clear and distinct idea of those problems that underlie the difficulties we experience in fact. The error of modern epistemologists was that they isolated the reflective stages of this process and hypnotized the elements of those stages into pre-existing constituents of a subjective mind in their search for an incorrigible foundation of knowledge. But Dewey thought that the hypnotization was as groundless as the search for incorrigibility was barren. In a troubled time like ours, a search for knowledge which denies the existence of any natural means and by extension, human means, to serve as a judgment of what is beneficial and nonbeneficial would only be workable for those who think that they possess superhuman means for attainment of ultimate ends[1] Dewey (1946).

The philosopher of the current age will not be concerned with a perfect realm, nor will he escape into a changeless reality. On the contrary, he will take part in the social strife of his time and attempt to apply his ideals to the betterment of social institutions[2] Mayer (1951). Little wonder, the 
rejection of a spectator theory of knowledge was a distinctive theme in Dewey's epistemology. For this kind of theory, knowledge was understood on the model of the observation of a fixed and independent object on the part of a subject. The spectator account of knowledge was accompanied by the quest for certainty in epistemology:

What can philosophies do which, in spite of change of conditions in science and in human affairs of basic import, go on occupying themselves with the problems of the conditions of knowledge in neglect of the vital problem of its consequences, actual and potential?.[3] Mayer (1951)

Dewey therefore aimed to displace this conception of knowledge with a notion of inquiry understood as the struggle of human intelligence to solve problems.

We find ourselves in situations that are qualified by their indeterminateness on the part of the experience; we call it a felt need. In more proper terms, we live in an incomplete universe; one that is loosely organized and pluralistic. That is why for Dewey: "A philosophic reconstruction which should relieve men of having to choose between impoverished and truncated experience on one hand and an artificial and impotent reason on the other would relieve human effort from the heaviest intellectual burden it has to carry"[4] Dewey (1921). The presence of change denotes instability, and instability is a sign of incompleteness and a defect. The hazards to which men are exposed are objective situations and when they are recognized as hazards, they become problematic situations which man seeks to resolve. Though Dewey differed from Hegel, he employed Hegel's dialectical process in his own philosophy. Put in another way, where there is change, there is plurality and multiplicity, and multiplicity brings opposition and strife. "Change is alteration, or othering and this means diversity. Diversity means division, and division means two sides and their conflict. The world which is transient must be a world of discord, for in lacking stability, it lacks the government of unity"[5] Dewey (1921). Contradiction therefore becomes a condition for progress. Where there is need and desire, there is incompleteness and insufficiency.

Dewey recognized the existence of various philosophical problems but avers that theories that are of importance to the worth of ideas are those which appeal to the person in question. However, he notes that the most urgent problem in our age is the restoration of interaction and co-operation between man's belief about the world in which he lives and about the purposes that should guide his conduct. On the final analysis, it becomes the prevalent problem in any philosophy that does not seek to divorce itself from existential realities. A philosophy which should take up this problem should take into cognizance beliefs about values that are not distinct from nature. For to assume that anything can be known in isolation from other things, is to associate knowing with mere presence of objects of perception. To the extent that we are able to make connections and interactions possible, to that extent also, is the resolution of a problematic situation assured [6] Dewey (1929). Dewey never conceived the incompleteness in nature as a deficiency, but as stepping stone to difficulties because for him, it is mainly under this condition that man is said to think constructively:

The conditions with which the farmer deals, whether as obstacles or resources, have their own structure and operation independently of any purpose of his. Seeds sprout, rain falls, the sun shines, insects devour, blight comes, the seasons change. His aim is simply to utilize these various conditions; to make his activities and their energies work together, instead of against one another... His purpose is simply a foresight of the consequences of his energies connected with those of the things about him... It is the same with the educator, whether parent or teacher...[7] Dewey (2009)

This underscores the fact that problematic situations are necessary phase not just for education but for life.

\section{The Theory of Experience}

What is experience? This puzzling question goes beyond mere definition. Traditionally, philosophers have held unto a concept of experience that remains at the level of contingency or particularity. The empiricists have also held to the view that to make the theory of experience tenable and acceptable, we must make do with what we have at the level of naturality, as the human person is devoid of Pure Reason that is capable of moving beyond the physical in a world of naturality. Hence, they contended that the alleged authority of a higher faculty has deterred man's progress.

Conceiving a new concept of experience must include two factors which are, the change that has taken place in the actual nature of experience, its contents and methods, as it is lived. The second is the development of a psychology which is biologically based and thus makes it possible to think of a new scientific notion of experience[8] Dewey (2009). From the psychological perspective, it avers that mental life is an off-shoot of sensation. The senses were regarded as a path through which knowledge is attained. The mind was therefore totally passive when it comes to the acquisition of knowledge. The intellectual, emotional and volitional activities were also present. However, the intellectual life took precedence over the emotional and volitional life respectively.

However, the influence of biology changed the whole conception of life. It postulates that wherever there is life, there is also activity, there is action. For life to persist, these activities and behaviour that are part of life would be constantly adjusted to suit the environment. Thus, it has a feature of being flexible and as such, it is constantly under revision. There ceases to be blind conformity of people and things to existential issues. There is room for debates, arguments and dialogues that keeps life going. As life therefore increases qualitatively, it becomes imperative for more reconstruction. Experience becomes an affair primarily of doing. What constitutes experience therefore is the close connection between doing and undergoing.

It is pertinent also to note how Dewey distinguished 
between a deed that is unconnected with its outcome; he sees it as being devoid of experience. There ought to be an act (even if it is aimless, random, without reflection and intention) before we can adequately say that doing and undergoing are connected. When this is achieved, then we can rightly say that the experience is vital and significant. From the perspective of the former, that is, the change that has taken place in the nature of experience; there is a line of antithetical thoughts that runs from ancient to modern period.

Plato viewed experience as that which enslaves man in his atavistic way of reasoning, thus relegating everything to custom. Reason for him is the only guide that can lift us from the dungeon of accidental past. Bacon and his adherents saw in Plato's view a conservative and enslaving element. Experience is the liberating power which is the new element that reveals novel facts and truths. Putting our faith in experience therefore guarantees progress. In search for mediation, its resolution is synonymous with the quest for balancing the relationship that exists between the real and the ideal in human endeavour. One wonders where the place of thinking in the whole process of experience lies. But it is worthy to state that both thinking and doing are resolved in the fact of experience. As Hook notes: "Thinking is an experience which mediates between other experiences"[9] Hook (1971). It springs from the immediacy that goes with enjoyment when a problematic situation or a dubious encounter is being resolved. Thinking therefore enriches immediate experiences.

Experience occurs in a continuous process because the interaction of living beings and environmental factors are in the process of living. We can say that we have an experience when what is under study or investigation runs its course to a worthwhile end. When a task is therefore finished in a satisfactory way, it is called an experience. Such an experience is marked by its own individuality and capacity to be self-sufficient. Experience is therefore defined in Dewey's view: “...by those situations and episodes that we spontaneously refer to as being real experiences"[10] Dewey (1934). An experience is not viewed in parts but taken holistically. Hence, the unity of an experience makes it possible to name such an experience.

Every experience that is marked by its unity moves towards a close and it only ceases when those activities that bestow power on it have completed their work properly. But we should however note that as all genuine education comes about through experience, not all experience is genuinely educative. No single experience has the capacity to complete itself. As it happens, something quickly enters into it to keep it going, or worthy of the name experience. An experience therefore has its own pattern and structure that consists of a relationship. Dewey gave an evident example of putting one's hands in fire. Mere putting the hand in fire is not an experience. It becomes an experience when it becomes consequential and joined in perception. It is the relationship of action and consequence that intelligence demands.

When we talk of experience, we also note that it includes the "experiences and reports of experiences of other men, living and dead, mature and immature, normal and abnormal... it covers anything and everything that can be denoted"[11] Eames (2003). It includes the past, the present and those things that have potentialities in the future. Experience therefore has a social character as it takes the knowledge, encounters and feelings of other human beings into consideration.

\section{Democracy and Progressive Education}

The notion of education as a social process and function has no definite meaning until we are able to define the kind of society that we have in mind. Democracy in its general term is often associated with a political system of administration. It is an off-shoot of a community of concepts which include; liberty, equality, fraternity and representation. Based on all these and some other concepts were to be founded some articles of the democratic faith, which was meant to guarantee a healthy living for man and his environment in the distant future. The common chorus was therefore nothing more than hope. This was also the rationale behind the advent of progressive education which in the 20th century was used to refer to ideas and practices that aim to make the school more effective in a democratic society. In their varying diversities, scholars or proponents of progressive system of education were similar in one respect, which was the fact that democracy entails active participation by all citizens in matters relating to their economic, social, cultural and even academic life. They were not just passive observers but also decision makers on issues that contribute to their existence and growth. There were various revolutions in commerce and communication that will eventually destroy the barriers that kept people apart from one another and which will also lead to lasting peace.

Another article that followed was a general development of enlightenment and rationality, which will eventually increase man's knowledge. There was also a general belief that governmental interference in the affairs of the people was a distortion of the natural law. With the presence of enlightenment and democratic institutions, this interference will gradually give way to the laws of naturality. Lastly, there was the belief in the fact that increase in production, which is consequential on industrial revolution, would increase the standard of living of the people thereby eliminating poverty to its barest minimum. With all these in mind, people in the world expected to notice some radical changes in various departments of operation, but the reverse was the case.

The quest for peace was replaced by various wars including the World Wars I and II respectively. The failure of collective and co-operative intelligence led to short-term intrusion by those who were concerned with making selfish profits to the detriment of the entire populace. Thus, it promoted greed, individualism, social instability and 
wastefulness of natural resources.

All these attitudes have consequences for education because those who attack these views of science base their argument on the fact that the curriculum as it was in schools gave more attention to science and to its application in vocational training. Hence, there was a quest to turn to the literary arts of the medieval period. The literary arts for some scholars would bestow credence on the knowledge of human nature that science and technology was being accused of relegating to the background. What would be the prospects of a reversal to the medieval period? Would that signify progress in the midst of contemporary methods in approaching issues? Past accomplishments and present moments ought to be used to enhance future projects, but not in the sense of dwelling in the past. If it happens thus, then the whole aim of an educational process that is constantly under revision is therefore defeated. The facticity of transformation and revolution become a sterile event.

Education would only be relevant in creating habits and secure a democratic and peaceful end as soon as human attitudes and efforts become the focal point for the promotion of peace, economic security and the promotion of freedom and equality. The solution to this situation does not lie in the extinction of scientific emphasis in schools, but in giving direction to a co-operative and collective human behavior[12] Dewey (1946).

The art of learning through which intelligence and character are developed does not only come from what the teacher alone has to say in the classroom. Every person becomes educated as soon as his or her contribution to the learning process is appreciated and meaningful. This is part of the heritage derived from a democratic society, where everyone is important and the part is as valuable as the whole. Democracy and education are therefore reciprocal, not in the sense of meaning the same thing, but in the sense that democracy is education, because in the democratic process lies also the art of learning.

Democracy is therefore connected to education simply because the articles of the democratic faith which include liberty, fairness, equality, etc, are to be built and developed within educational institutions. What makes education experiential is the fact that the school is not an environment where theoretical principles are taught. Also, the society is not a place where those theories are put into use. They ought to have been lived within the educational environment, while the society serving as a continuum of the same process. It is on this note that experience can become holistic. If the society is invaded by people who are not able to think independently, it is because first and foremost, the school condition under which students are nurtured is that which enables them to simply follow rules.

People live in a community by virtue of those things that they share in common and communication is the medium through which they possess those things in common. Aims, beliefs, aspirations and knowledge are the values they must have in common in order to form a society. All these values must in turn be guided by the role of the educator if the enterprise of education is to furnish the environment that stimulates responses and directs the course of learners. In the moral sphere, all education which develops power to share in social life is moral.

\section{The African Experience}

In some countries on the African continent, there is loosed system of government and that is why the basic problem with our political system is that corruption reigns with absolute sovereignty. Thus, because the masses are not free to speak in opposition to bad governance, every administration that comes afterwards has every reason to be corrupt. The freedom of expression which is necessary in this regard ought to be established in the educational system, but since what is obtainable in many African countries is a system of education based on obedience to rules by students, educational dictatorship is on the increase and the resultant effect on the society are graduates who have no independent thought of their own capable for societal progress.

Those who attempt the advocacy of strong political structures for the development of African societies have link with practical western system of education. The adamant nature of African politicians to transcend individualistic inclinations makes sane political structures impossible. The sole reason that educational policies cannot be put into effective use is because it endangers the ill motives of many top public officers who would prefer their citizens to remain in bondage permanently because the freedom that education guarantees is that which liberates the human person and sends him forth:

The self-professed aim of modern education is to liberate people from prejudices and traditional forms of authority. Educated people are said not to obey authority blindly, but rather learn to think for themselves.[13] Fukuyama (1992)

Like the slave-master morality of Nietzsche, the freedom of the slave becomes a source of worry for the master because power is only relevant where there are subjects which serve as outlets to vent such power. The freedom of the citizens threatens the existence of the bourgeois. It is a situation where the awareness of the proletariat endangers the bourgeois as increase in their awareness decreases their capacity to be trampled upon by the bourgeois. How can they exercise their lordship over the vast majority by dictating how to run the resources of the state if they are allowed to go through progressive education that liberates them?

The reason why political systems are devoid of workable ideologies is either because they have no aim(s) or because they have blurred aims/visions, and because a sterile aim cannot give birth to an end that is clear and distinct, it recoils in a vicious circle back to the educational institutions. The Nigerian educational sector like many other systems in Africa thinks 'per game'; impliedly, they lack workable ideological framework that encourages continuity. Political leaders have always been empowered to choose educational leaders. The result is that an aimless political system which necessarily will have no end in view 
dictate what the good of students shall be through the educationists that man the educational system and since colonialism is not a prerequisite for slavery, pupils become tools to be manipulated upon within democratic systems. Such situations occur primarily where "rulers are simply interested in such training as will make their subjects better tools for their own intentions"[14] Dewey (2009). When we speak of rulers in this sense, we also refer to their privies. On this note therefore, we classify the educated elites into two categories; those who attend schools bearing in mind the result of the educational training they acquire and those who attend school bearing in mind that educational formation is incomplete until results lead to ends. Rulers and their privies who must continue to exercise their lordship over the vast majority belong to the second category, while the manipulated majority belongs to the first category. This is perfectly illustrated in the analogy of the rabbit; when one aims at a rabbit:

What he wants is to shoot straight...it is not rabbit apart from his activity, but as a factor in activity; he wants to eat the rabbit, or to show it as evidence of his marksmanship he wants to do something with it. The doing with the thing, not the thing in isolation, is his end.[15] Dewey (2009)

It is this divide that brings to bear the notion of educational inequality. Equality in this sense is used in terms of equal opportunity towards attaining goals. Constitutions of various countries in the world may have enshrined those principles at various levels, but our experience shows that what exists is de jure equality and not de facto equality. Using Nigeria as a case study, we are apt to say that the education of the citizens is irrelevant as long as it does not affect the few in position of power who are capable of projecting their wills, while providing quality educational training for their children. While both education and security are important, to the extent that some are in urgent need of security, to that same extent is the hunger for qualitative education paramount in the minds of others. It is under such conditions that the Americans are considered to be equal, because though not all for instance could afford the financial obligations of the most expensive colleges, it never prevented those who are of low financial status from the right to qualitative education; only in a participatory democracy is this attainable.

Education does not bestow qualitative goals simply because it is not a living person; it is only possible where the human (rational) element is involved. Thus, human beings and not education give aim, result and purpose to the educational system; they breathe the air for a formidable educational system through workable policies. It is very clear that those who should make a clear ground for a stable system are not in the first place ignorant of what it entails to install leadership in the system; our problem is that of working with sincere motives, hence the problem of good governance for development. But until we know how it works and how to work it, we are not educated. Hence, one of the basic necessities to make it workable is the conscientious element of the human person.
There is need for some sort of mental emancipation that will disturb the old equilibrium; a level of genuine ideological war that reverses the reasoning of the elites and the trampled majority, so as to bridge the gap that has long existed between both groups of people in the African society. If we are able to underscore the fact that the goal of education goes beyond results, Africa's political system will in the future become an extension of same ideology that democracy and governance is not just defined by results but by ends.

\section{Conclusion}

Life is not a sequence of knowledge and action, but should rather be one of knowledge in action. Education does not launch us into the society in the fictional way that we perceive, so that when we are done with school, we drop our values in search of new ideas. Education should not therefore merely prepare us for life, it should be considered as part of life itself. There is need to therefore bridge the gap that had long existed between life in school and society as the problems of education will eventually become the fundamental problems of democracy.

\section{References}

[1] John Dewey, Problems of Men, (New York: Philosophical Library, 1946), p. 10.

[2] Frederick Mayer, American Thought. An Introduction, (Iowa: WM.C. Brown Co. Pub; 1951), p. 311.

[3] Ibid. p. 71.

[4] John Dewey, Reconstruction in Philosophy, (London: University of London Press Limited, 1921), p.101.

[5] Ibid. p. 108.

[6] John Dewey, The Quest for Certainty: A Study of the Relation of Knowledge and Action, (New York: Minton Balch \& Co; 1929), p. 267.

[7] John Dewey, Democracy and Education, (USA: Unabridged Version, 2009), p. 48.

[8] Ibid. pp. 83-84.

[9] Sidney Hook, John Dewey: An Intellectual Portrait, (Westport: Greenwood Press Publishers, 1971), p. 193.

[10] John Dewey, Art as Experience, (New York: Capricon Books, 1934), p. 36.

[11] Elizabeth Eames, Experience and Value. Essays on John Dewey and Pragmatic Naturalism. (Carbondale: Southern Illinois University Press, 2003), p. 15

[12] John Dewey, Problems of Men, p. 31.

[13] Francis Fukuyama, The End of History and the Last Man, (London: Penguin Books, 1992), p. 116.

[14] John Dewey, Democracy and Education, p. 43.

[15] Ibid. p. 48. 